\title{
PENGARUH CURRENT RATIO, RETURN ON ASSET DAN EQUITY PADA MODAL KERJA
}

\author{
Sudarti ${ }^{1}$, Herman Sjahruddin ${ }^{2}$, Orfyanni S Themba ${ }^{3}, \&$ Ardiansyah Halim ${ }^{4}$ \\ 1,2,3,4 Program Studi Manajemen, Sekolah Tinggi Ilmu Ekonomi Bongaya Makassar \\ EmaiL: ayhu007@gmail.com
}

\begin{abstract}
This study aims to determine the effect of Current Ratio, Roa, and Roe on Working capital at PT. Unilever Indonesia, Tbk. The study population was the quarterly financial reports, 2008-2018 using by totalling sampling in sampling so that $4 \times 11=44$ data units were obtained as the sample. Data analysis used multiple linear regression through the use of SPSS Ver.25. The analysis shows that the current ratio and return on assets have a significant positive effect and the other causality showing return on equity has a significant negative effect on working capital.
\end{abstract}

Keywords : Current ratio; return on asset; equity; working capital;

\begin{abstract}
Abstrak: Penelitian ini bertujuan untuk mengetahui pengaruh Current Ratio, Roa dan Roe terhadap Modal kerja pada PT. Unilever Indonesia, Tbk. Populasi penelitian adalah Laporan keuangan triwulan, Tahun 2008 - 2018 dengan menggunakan total sampling, sehingga diperoleh $4 \times 11=44$ unit data sebagai sampel. Analisis data menggunakan regresi linear berganda melalui pemanfaatan SPSS Ver. 25. Analisis data membuktikan jika current ratio dan return on asset berpengaruh positif signifikan terhadap modal kerja sementara return on equity negatif signifikan terhadap modal kerja.
\end{abstract}

Keywords : Current ratio, return on asset, equity, modal kerja 


\section{PENDAHULUAN}

Modal kerja diperlukan perusahaan untuk membiayai kegiatan operasional perusahaan karena modal kerja memiliki kepentingan terhadap tinggi rendahnya profitabilitas dalam mencapai tujuan setiap perusahaan. Modal kerja diartikan sebagai investasi yang ditanamkan dalam aktiva lancar atau aktiva jangka pendek, seperti kas, bank, surat-surat berharga, piutang persediaan, dan aktiva lancar lainnya. Modal kerja adalah kelebihan aktiva lancar terhadap utang jangka pendek. Kelebihan ini disebut modal kerja bersih (net working capital). Kelebihan ini merupakan jumlah aktiva lancar yang berasal dari utang jangka panjang dan modal sendiri (Kasmir, 2013:250).

Terdapat faktor yang mempengaruhi jumlah modal kerja yaitu waktu untuk memproduksi atau mendapatkan barang dan ongkos produksi per unit atau harga beli per unit barang tersebut. Makin panjang waktu yang diperlukan untuk memproduksi barang atau memperoleh barang makin besar kebutuhan akan modal kerja. Modal kerja bervariasi tergantung pada volume pembelian dan harga beli per unit dari barang yang dijual (Djumimgan, 2014:69). Faktor lain yang mempengaruhuhi modal kerja yaitu current ratio, return on asset (ROA) dan return on equity(ROE), hasil temuan peneliti terdahulu menunjukan bahwa Profitabilitas (ROA dan ROE) dan likuiditas (current ratio) berpengaruh positif dan signifikan terhadap modal kerja (Satar dan Haelani, 2016; Priandini dan Lubis, 2019; Anggarani dan Ficilia, 2014; Priandini dan Lubis, 2019).

Temuan peneliti tersebut relevan dengan pecking order theory (Myers dan Majluf, 1984; dalam Denziana dan Yunggo, 2017) bahwa perusahaan akan mengutamakan dana internal untuk melakukan perluasan usaha. Dana internal tersebut berasal dari saldo laba. Apabila dana internal yang dimiliki perusahaan terbatas, maka manajer akan mencari alternatif pendanaan yang berasal dari luar perusahaan, yaitu dari utang ataupun penerbitan saham. Perusahaan dengan tingkat profitabilitas yang tinggi justru tingkat hutangnya rendah, dikarenakan perusahaan yang profitabilitasnya tinggi memiliki sumber dana yang berlimpah, dalam packing order theory tidak terdapat modal kerja yang optimal (Denziana dan Yunggo, 2017).

Perusahaan Unilever Indonesia, Tbk (UNVR) mengalami penurunan (negative) dengan menggunakan hasil perhitungan aktiva lancar dikurang hutang lancar yang ada pada laporan keuangan perusahaan. Modal kerja adalah kelebihan aktiva lancar terhadap hutang jangka pendek. Kelebihan ini berasal dari hutang jangka panjang dan modal sendiri yang disebut dengan modal kerja bersih (net working capital). Modal kerja dapat dipengaruhi oleh tingkat likuiditas perusahaan apabila perusahaan tersebut memiliki kewajiban (hutang) jangka pendeknya terhadap kreditur (Djarwanto, 2011:87).

Fakta empiris yang diperoleh dari laporan keuangan perusahaan menunjukkan modal kerja perusahaan cenderung mengalami penurunan, ditunjukkan pada Tabel berikut :

Tabel: 1 Modal Kerja PT. Unilever Indonesia Tbk. Periode 2016-2018 (dalam Trilyunan Rupiah)

\begin{tabular}{cccc}
\hline Tahun & $\begin{array}{c}\text { Aktiva } \\
\text { lancar }\end{array}$ & $\begin{array}{c}\text { Hutang } \\
\text { Lancar }\end{array}$ & $\begin{array}{c}\text { Modal } \\
\text { Kerja }\end{array}$ \\
\hline 2016 & 6.588 .109 & 10.878 .074 & -4.289 .965 \\
2017 & 7.941 .635 & 12.532 .304 & -4.590 .669 \\
2018 & 9.476 .988 & 14.412 .037 & -4.035 .049 \\
Mean & 8.002 .244 & $12.607 .471,67$ & -4.305 .228 \\
\hline
\end{tabular}

Sumber : www.idx.co.id / Data diunduh, 2020

Berdasarkan tabel 1.1 maka dapat dijelaskan bahwa selama 3 tahun modal kerja perusahaan mengalami negatif atau fluktuasi setiap tahunnya. Hal ini disebabkan karena hutang lancar lebih tinggi di banding aktiva lancar. Hasil perbandingan laporan keuangan PT. Unilever Indonesia Tbk menunjukkan bahwa modal kerja yang di peroleh belum optimal atau mengalami fluktuasi yaitu terjadi penurunan. Mengacu pada fakta lapangan tersebut maka menjadi alasan peneliti untuk melakukan penelitian.

\section{Tujuan Penelitian}

Penelitian ini bertujuan untuk menguji dan menganalisis pengaruh :

1. Current Rasio terhadap modal kerja.

2. ROA terhadap modal kerja.

3. ROE terhadap modal kerja.

4. Variabel dominan terhadap modal kerja.

\section{TINJAUAN PUSTAKA}

\section{Manajemen Keuangan}

Manajemen keuangan dapat diartikan sebagai manajemen baik yang berkaitan dengan pengalokasian dana dalam berbagai bentuk investasi secara efektif maupun usaha pengumpulan dana untuk pembiayaan investasi atau pembelanjaan secara efisien (Sartono, 2014:6).

\section{Laporan Keuangan}

Laporan keuangan adalah sebagai suatu informasi yang menggambarkan kondisi suatu perusahaan, dimana selanjutnya itu akan menjadi suatu informasi yang menggambarkan kinerja suatu 
perusahaan. Pengertian laporan keuangan perusahaan tersebut menunjukkan bahwa laporan keuangan adalah output dari proses akuntansi yang menjadi bahan informasi bagi para pemakainya dalam pengambilan keputusan (Fahmi, 2012:22).

\section{Pasar Modal}

Pasar modal dapat dikatakan pasar abstrak, dimana yang diperjualbelikan adalah dana dana jangka panjang, yaitu dana yang keterikatannya dalam investasi lebih dari satu tahun (Widoatmodjo, 2012:15)

\section{Pecking Order Theory}

Myers dan Majluf (1984) menjelaskan keputusan pendanaan yang diambil oleh perusahaan. Pemanfaatan Packing order theory dalam penelitian ini dapat dijelaskan bahwa kemampuan perusahaan untuk memperoleh laba akan mengutamakan dana internal perusahaan untuk melakukan perluasan usaha. Semakin rendah penggunaan hutang perusahaan maka kemampuan perusahaan untuk memperoleh laba semakin meningkat. Sebaliknya, semakin tinggi tingkat penggunaan hutang perusahaan mengindikasikan kemampuan perusahaan untuk memperoleh laba akan semakin menurun karena umumnya perusahaan akan lebih memilih menggunakan pendanaan internal daripada eksternal (Sianipar dan Ibrahim, 2017)

\section{Modal Kerja}

Modal kerja juga diartikan seluruh aktiva lancar yang dimiliki suatu perusahaan atau setelah aktiva lancar dikurangi dengan utang lancar. Atau dengan kata lain modal kerja merupakan investasi yang ditanamkan dalam aktiva lancar atau aktiva jangka pendek, seperti kas, bank, surat berharga, piutang, persediaan, dan aktiva lancar lainnya. biasanhya modal kerja digunakan untuk beberapa kali kegiatan dalam satu periode (Kasmir, 2010:300).

\section{Current Ratio}

Rasio lancar atau (current ratio) merupakan rasio untuk mengukur kemampuan perusahaan dalam membayar kewajiban jangka pendek atau utang yang segera jatuh tempo pada saat ditagih secara keseluruhan (Kasmir,2019: 134).

\section{Return On Asset (ROA)}

Return on asset (ROA) menunjukkan kemampuan perusahaan dengan menggunakan seluruh aktiva yang dimiliki untuk menghasilkan laba setelah pajak. Semakin besar ROA, berarti semakin efisien penggunaan aktiva perusahaan atau dengan kata lain dengan jumlah aktiva yang sama bias dihasilkan laba yang besar, dan sebaliknya (Sudana dkk, 2015:26).

\section{Return On Equity (ROE)}

Hasil pengembalian Ekuitas (Return on Equity) atau rentabilitas modal sendiri merupakan rasio untuk mengukur laba bersih sesudah pajak dengan modal sendiri. Semakin tinggi rasio ini berarti semakin efisien penggunaan modal sendiri yang dilakukan oleh pihak perusahaan (Sudana, 2011:22)

\section{Pengaruh Current ratio terhadap modal kerja}

Current ratio digunakan untuk menghitung kemampuan perusahaan dalam membayar utang lancar dengan aktiva lancar yang tersedia, yaitu dengan cara membandingkan aktiva lancar dengan hutang lancar. Kemampuan perusahaan di dalam memenuhi kebutuhan kas untuk membayar kewajiban jangka pendek maupun untuk membiayai operasional sehari-hari sebagai modal kerja. Semakin baik rasio lancar suatu perusahaan, maka perusahaan akan mendapatkan kepercayaan dari para kreditur, sehingga kreditur tak akan ragu meminjamkan dana mereka yang digunakan perusahaan untuk menambah modal yang nantinya akan memberikan keuntungan bagi perusahan (Meidiyustiani, R. 2016).

Berdasarkan pernyataan, tersebut maka dirumuskan hipotesis pertama dalam penelitian ini, yaitu :

$\mathrm{H}_{1}$ : Current ratio berpengaruh positif dan signifikan terhadap modal kerja

\section{Pengaruh Return on asset terhadap modal kerja}

Return on asset merupakan kemapuan perusahaan menunjukkan keberhasilan perusahaan dalam menghasilkan laba dengan seluruh asset yang dimiliki oleh perusahaan. Memberikan ukuran yang lebih baik atas profitabilitas perusahaan karena menunjukkan efektivitas manajemen dalam menggunakan asset untuk mendapatkan keuntungan. Semakin besar nilai roa menunjukkan kinerja perusahaan semakin baik (Haryanto, 2019 ; Satar dan Haelani, 2016).

Berdasarkan pernyataan, tersebut, maka dirumuskan hipotesis kedua dalam penelitian ini, yaitu :

$\mathrm{H}_{2}$ : Return on asset berpengaruh positif dan signifikan terhadap modal kerja

\section{Pengaruh Return on equity terhadap modal kerja}

Return on equity digunakan untuk membandingkan laba bersih sesudah pajak dengan modal sendiri dengan tujuan mengukur tingkat penghasilan bersih yang diperoleh oleh pemilik 
perusahaan atas modal yang diinvestasikan. Pengukuran dari suatu penghasilan (income) yang tersedia bagi para pemilik perusahaan atas modal yang mereka investasikan didalam perusahaan. Secara umum semakin tinggi return atau penghasilan yang di hasilkan maka akan semakin baik kedudukan pemilik perusahaan. Rasio ini menunjukkan hubungan antara modal kerja dengan penjualan yang dapat diperoleh perusahaan untuk tiap rupiah modal kerja (Anggarani dan Ficilia, 2014).

Berdasarkan pernyataan, tersebut, maka dirumuskan hipotesis ketiga dalam penelitian ini, yaitu :

$\mathrm{H}_{3}$ : Return on equity berpengaruh positif dan signifikan terhadap modal kerja

\section{Pengaruh dominan antara Current ratio, Return on asset dan Return on equity terhadap modal kerja}

Semakin tinggi rasio profitabilitas (roa dan roe) menunjukkan kinerja perusahaan semakin baik. Semakin baik rasio lancar suatu perusahaan, maka perusahaan akan mendapatkan kepercayaan dari para kreditur, sehingga kreditur tak akan ragu meminjamkan dana mereka yang digunakan perusahaan untuk menambah modal yang nantinya akan memberikan keuntungan bagi perusahan (Anggarani, D., dan Ficilia, I. 2014).

Berdasarkan pernyataan, tersebut, maka dirumuskan hipotesis ke-empat dalam penelitian ini, yaitu :

$\mathrm{H}_{4}$ : Return on asset dominan berpengaruh positif dan signifikan terhadap modal kerja.

\section{METODE PENELITIAN}

\section{Teknik Pengumpulan Data}

Teknik pengumpulan data yang digunakan dalam penelitian ini adalah teknik dokumentasi yaitu teknik yang dilakukan dengan cara mengumpulkan, mencatat, dan mengkaji data sekunder yang berupa laporan keuangan perusahaan PT. Unilever Indonesia, Tbk. Teknik sampling yang di gunakan dalam penelitian ini adalah sampling jenu. Sampling jenu adalah teknik pengumpulan sampel bila semua anggota populasi dijadikan sampel (Sugiyono 2017:124). maka jumlah sampel yang digunakan dalam penelitian ini adalah triwulan dikalikan dengan Tahun pengamatan (4 x 11 = empat puluh empat unit data) .

\section{Operasionalisasi Variabel}

Penelitian variabel ini menggunakan current ratio, return on asset, dan return on equity sebagai variabel independen, selanjutnya modal kerja sebagai variabel dependen. Adapun definisi dan pengukuran variabel dalam penelitian ini adalah :

\section{Independent variable}

Variabel bebas sering disebut variabel stimulus, predictor, atau variabel antecendent. Dalam bahasa indonesia sering disebut variabel bebas. Variabel bebas merupakan variabel yang mempengaruhi atau yang menjadi sebab perubahannya atau timbulnya variabel dependen (terikat). (Sugiyono, 2013:61). Variabel bebas dalam penelitian ini adalah current ratio, roa, dan roe.

a) Current Ratio

Rasio lancar merupakan rasio untuk mengukur kemampuan perusahaan dalam membayar kewajiban jangka pendek atau utang yang segera jatuh tempo pada saat ditagih secara keseluruhan (Kasmir, 2016). Rasio ini dapat dirumuskan:

$C R=\frac{\text { Aktiva Lancar }(\text { Current Assets })}{\text { Hutang Lancar }(\text { Current Liabilities }} \times 100 \%$

b) Return On Asset (ROA)

Return on asset (ROA) menunjukkan kemampuan perusahaan dalam menghasilkan laba atas aktiva yang dipergunakan. Semakin tinggi rasio ini semakin baik keadaan suatu perusahaan. Apabila tingkat ROA itu rendah, tidak selalu berarti buruk. Hal tersebut dapat dapat diakibatkan oleh keputusan yang disengaja untuk menggunakan utang dalam jumlah besar, bebann bunga yang tinggi menyebabkan laba bersih menjadi relative rendah (Brigham dan Houston, 2010:148). Rumus untuk mehitung ROA yaitu:

Return On Asset $(R O A)=\frac{\text { Earning After } \text { Taxes }}{\text { total Assets }}$

c) Return On Equity (ROE)

Return on Equity merupakan kemampuan perusahaan memperoleh laba yang tersedia bagi pemegang saham perusahaan. Rasio ini dipengaruhi oleh besar kecilnya utang perusahaan, apabila proporsi utang besar maka rasio ini akan besar (Sartono,2012: 124). Rumus untung menghitung ROE adalah sebagai berikut:

Return On Equity $(R O E)=\frac{\text { Earning After Taxes }}{\text { Equity }}$

1. Variabel terikat (dependent variable)

Variabel terikat atau dependent variable merupakan variabel yang dipengaruhi atau yang 
menjadi akibat, karena adanya variabel bebas. Sugiyono (2013:61). Variabel terikat yang dimaksud dalam peneliti adalah Modal Kerja atau variabel $\mathrm{Y}$.

a. Modal kerja

Modal kerja adalah kelebihan aktiva lancar terhadap hutang jangka pendek. Kelebihan ini berasal dari hutang jangka panjang dan modal sendiri yang disebut dengan modal kerja bersih (net working capital. Modal kerja adalah jumlah harta lancar yang merupakan bagian dari investasi yang bersirkulasi dari satu bentuk ke bentuk yang lain dalam suatu kegiatan bisnis (Kasmir, 2013:248). Pendapat tersebut relevan dengan pendapat ahli lainnya bahwa Modal kerja merupakan ukuran tentang keamanan sari kepentingan kreditur jangka pendek (Harahap, 2015:288) Dengan rumus untung menghitung modal kerja adalah sebagai berikut:

$$
\begin{aligned}
\text { Modal kerja }= & \text { aktiva lancar } \\
& - \text { hutang lancar }
\end{aligned}
$$

\section{Metode Analisis}

Penelitian ini meupakan penelitian deskriptif dengan regresi linear berganda, menggunakan desain penelitian cross sectional.Data kuantitaf digunakan untuk meneliti pada populasi atau sampel tertentu, analisis data bersifat statistik sehingga dapat dianalisis dengan alat statistik (Sugiyono, 2017:8). Menggunakan analisis regresi linier berganda dengan model persamaan sebagai berikut :

$$
\begin{array}{lll}
\mathrm{Y}=\mathrm{a}+\left(\beta_{1} \mathrm{X}_{1}\right) & \left.+\left(\beta_{2} \mathrm{X}_{2}\right)+\beta_{3} \mathrm{X}_{3}\right)+\mathrm{e} \\
\text { Keterangan : } & \\
\mathrm{Y} & = & \text { Modal Kerja } \\
\mathrm{X}_{1} & = & \text { Current Ratio } \\
\mathrm{X}_{2} & = & \text { Return On Asset } \\
\mathrm{X}_{3} & = & \text { Return On Equity } \\
\mathrm{A} & = & \text { Konstanta } \\
\beta_{1}, \beta_{2}, \beta_{3} & = & \text { Koefisien Regresi } \\
\mathrm{E} & = & \text { Epsilon atau variabel tidak } \\
& & \text { terungkap (error) }
\end{array}
$$

\section{HASIL DAN PEMBAHASAN}

\section{Pengujian $B L U E$}

\section{a. Kesesuaian data}

Tabel 2. Kenormalan

\begin{tabular}{l}
\hline Sebaran data \\
\hline t-hit \\
p-value \\
Sumber : Data diolah (2020) \\
Hasil uji normalitas diatas diperoleh nilai \\
signifikan unstandarzed residual sebesar 0,101 >
\end{tabular}

0.5 sehingga dapat diambil kesimpulan bahwa data yang digunakan dalam penelitian ini terdistribusi normal.

\section{b. Kebersinggungan data}

Hasil menunjukkan jika data yang dianalisis tidak menunjukkan adanya autokolerasi dibuktikan dengan nilai dL sebesar 1.3749 dan nilai dU sebesar 1.6647, karena nilai dW 1.015 lebih kecil dari nilai $\mathrm{dU}$ dan lebih besar dari (4-Du) ( $\mathrm{Du}>\mathrm{d}>4-\mathrm{Du})$.

\section{c. Gangguan hubungan data}

Tabel 3. Kebersinggungan data

\begin{tabular}{lrr}
\hline Pengukur & Toleransi & Influence Factors \\
\hline CR & .405 & 2.466 \\
ROA & .064 & 5.653 \\
ROE & .051 & 9.540 \\
\hline
\end{tabular}

Sumber : Data diolah (2020)

Hasil pengujian nilai Tolerance variabel CR sebesar $0,405<1$ dan ROA $0.063<1$ dan ROE $0.050<1$, sehingga dengan demikian bahwa pada pengujian tolerance tidak terja multikolinieritas. Sementara itu, nilai VIF CR $2.466<10$ dan ROA $5.653<10$, ROE $9.540<10$, sehingga dinyatakan tidak terjadi gangguan multikolinieritas.

\section{d. Hetero}

Tabel 4. Glesjer

\begin{tabular}{lll}
\hline Predictor & t-hit. & p-value \\
\hline CR & -0.415 & 0.086 \\
ROA & -0.251 & 0.675 \\
ROE & 0.018 & 0.978 \\
\hline
\end{tabular}

Sumber : Data diolah (2020)

Berdasarkan data diatas diketahui bahwa nilai pvalue pada CR sebesar $0.086>0.05$, ROA sebesar $0,675>0.05$ sebesar dan ROE $0.978>0.05$, sehingga hasil tersebut mengindikasikan bahwa tidak terjadi heteroskedastisitas.

\section{e. Arah data}

Tabel 5. Kesesuaian Arah

\begin{tabular}{lc}
\hline Causality & Sig. \\
\hline Mod_Kerja * CR & \\
Mod_Kerja * ROA & .109 \\
Mod_Kerja * ROE & .115 \\
\hline
\end{tabular}

Sumber : Data diolah (2020)

Hasil pengujiian kesesuaian arah data menunjukkan jika ketiga predictor yaitu CR, ROA, dan ROE $\rightarrow$ modal kerja $>0,005$, sehingga ketiga kausalitas yang diuji menunjukkan adanya kesesuaian arah data. 
2. Analisis statistic deskriptif

Tabel 6. Deskriptif

\begin{tabular}{lcc}
\multicolumn{1}{c}{ Penjelas } & Mean & Stdv \\
\hline CR & 84,409 & 17,010 \\
ROA & 56,181 & 36,651 \\
ROE & 164,772 & 121,288 \\
Modal Kerja & $-16668,977$ & 15474,881 \\
\hline
\end{tabular}

Sumber : Data diolah (2020)

Dapat dilihat dari Tabel 6 bahwa variabel CR dengan jumlah data (N) 44 mempunyai persentase rata-rata sebesar 84,409 dengan standard deviasi 17.010

Variabel ROA dengan jumlah (N) 44 mempunyai persentase rata-rata sebesar 56,181 dengan standard deviasi 36.651.

Variabel ROE dengan jumlah (N) 44 mempunyai persentase rata-rata sebesar 164,772 dengan standard deviasi 121,288

Variabel modal kerja cenderung dengan jumlah (N) sebanyak 44 mempunyai persentase rata-rata sebesar -16668,977 dengan standard deviasi 15474,881 .

\section{Analisis Regresi Berganda}

Hasil analisis regresi linear terhadap variabel penelitian sebagai berikut:

Tabel 7. Regression testing

\begin{tabular}{lll}
\hline Predictor & t-hit. & p-value \\
\hline CR & 8,787 & 0.000 \\
ROA & 5,465 & 0.000 \\
ROE & $-5,964$ & 0.000 \\
\hline
\end{tabular}

Sumber : Data diolah (2020)

$$
\begin{aligned}
\mathrm{Y}_{(\text {Modal kerja })=} & -65349,770(\text { konstanta) } \\
& +600,162(\mathrm{CR}) \\
& 6894,5022_{(\mathrm{ROA})}-160,804(\mathrm{ROE})+
\end{aligned}
$$

Persamaan regresi tersebut, dapat dijelaskan sebagai berikut:

a. Angka konstanta sebesar $-65349,770$ menyatakan jika current ratio, ROA dan ROE konstan atau sama dengan nol (0), maka besarnya modal kerja nilainya sebesar 65349,770

b. Koefisien CR sebesar 600,162 menyatakan bahwa setiap penambahan $1 \% \mathrm{CR}$, maka akan meningkatkan modal kerja sebesar 600,162 pada saat variabel lainnya tetap.

c. Koefisien ROA sebesar 436,402 menyatakan bahwa setiap penambahan 1\% ROA, maka akan meningkatkan modal kerja sebesar 436,402pada saat variabel lainnya tetap.

d. Koefisien ROE sebesar $-160,804$ menyatakan bahwa setiap penambahan $1 \%$ ROE, maka akan meningkatkan modal kerja sebesar -160,804 pada saat variabel lainnya tetap.

\section{Uji determinasi $(\mathbf{R})$}

Ketiga variabel bebas memberikan sumbangan dalam penciptaan modal kerja perusahaan sebesar 0,909 atau 90,90 \%, sedangakan untuk kontribusi dari masing-masing variabel independen dapat ditunjukkan sebagai berikut:

Tabel 8. Kontribusi Prekdiktor

\begin{tabular}{cccccc}
\hline $\begin{array}{c}\text { Variabel } \\
\text { Indp. }\end{array}$ & $\begin{array}{l}\text { Person } \\
\text { Korelasi }\end{array}$ & $\rightarrow$ & $\begin{array}{c}\text { Stdv. } \\
\text { Coefficients }\end{array}$ & Kontribusi \\
\hline CR & 1 & $\mathrm{X}$ & 0,660 & $=$ & 0,66 \\
ROA & $-0,668$ & $\mathrm{X}$ & 1,034 & $=$ & $-0,690$ \\
ROE & $-0,746$ & $\mathrm{X}$ & $-1,260$ & $=$ & 0,939 \\
\hline \multicolumn{7}{r}{ Total besaran pengaruh (R square) } & $=$ & 0,909 \\
\hline
\end{tabular}

Sumber : Data diolah (2020)

Kontribusi pengaruh $\mathrm{CR}$ terhadap modal kerja sebesar $66,00 \%$, pengaruh ROA terhadap modal kerja sebesar $-69,00 \%$ sedangkan ROE terhadap modal kerja sebesar $93,90 \%$ sehingga jika dibulatkan maka diperoleh besaran kontribusi (koefisien determinasi) sebesar 0,909248 atau 90,92 $=90,92 \%$ (R Square). Berdasarkan hasil tersebut dapat dijelaskan bahwa kontribusi dominan variabel yang mempengaruhi variabel modal kerja adalah ROE dengan total kontribusi 93,90\%.

\section{Uji Fisher test (Uji-F/uji kelayakan model)}

Penggunaan uji-F dilakukan untuk menilai apakah model yang dianalisis telah memenuhi syarat kelayakan model (goodness of fit model) dasar pengambilan keputusan terbukti atau tidaknya hipotesis yang diajukan yaitu jika nilai $\mathrm{F}_{- \text {hitung }}>\mathrm{F}$ tabel dan pada tingkat signifikansi $<0.05$, maka model dinyatakan layak untuk dianalisis lebih lanjut. Hasil pengujian dapat dilihat pada tabel di bawah ini:

Tabel 9. Kekuatan Model

\begin{tabular}{|l|l|l|}
\hline Konstrak & f-statistik & Prob. \\
\hline Regression & 1,465 &, 239 \\
\hline
\end{tabular}

Sumber : Data diolah (2020)

Berdasarkan hasil pengolahan menunjukan hasil pengujian model diperoleh nilai $\mathrm{F}_{\text {-hitung }}$ sebesar 1,465 dan nilai $F$-tabel 2,8387 dengan derajat kekeliruan $5 \%(\alpha=0,05)$ dan derajat bebas $(3 ; 40)$ sehingga diperoleh $\mathrm{F}_{\text {-tabel }}$ sebesar 2.8387. Oleh karena itu, hasil tersebut menunjukan bahwa nilai 
$\mathrm{F}_{\text {-hitung }}>\mathrm{F}_{\text {-tabel }}$ yang menunjukan bahwa model tersebut layak (memenuhi kriteria model).

\section{a. Uji Stundet test (t-test)}

Uji t-statistik pada dasarnya menunjukkan seberapa jauh pengaruh satu variabel penjelas (independen) secara individual dalam menerangkan variasi variabel dependen. $\mathrm{Uji} \mathrm{t}-$ statistik mempunyai nilai signifikansi $\alpha=5 \%$. Kriteria pengujian hipotesis dengan menggunakan uji statistik $\mathrm{t}$ adalah jika nilai signifikansi $\mathrm{t}$ ( $\mathrm{p}$-value) < 0,05, maka hipotesis alternatif diterima, yang menyatakan bahwa suatu variabel independen secara individual dan signifikan mempengaruhi variabel dependen (Ghozali, 2016 : 98).

1) $\mathrm{t}_{\text {hitung }}>\mathrm{t}_{\text {tabel }}$ : maka $\mathrm{HO}$ ditolak dan $\mathrm{Ha}$ diterima

2) $\mathrm{t}_{\text {-hitung }}<\mathrm{t}_{\text {tabel }}$ : maka HO diterima dan Ha ditolak

\section{4. uji-t}

Tabel 10. Hasil Uji Student Test (t-test)

\begin{tabular}{ccc}
\hline Konstrak & t-statistik & Prob \\
\hline (Constan) & $-9,478$ &, 000 \\
CR & 8,787 &, 000 \\
ROA & 5,465 &, 000 \\
ROE & $-5,964$ &, 000 \\
\hline
\end{tabular}

Sumber : Data diolah (2020)

Berdasarkan penjelasan terhadap hasil tersebut, dapat diuraikan sebagai berikut :

1) Pengaruh current ratio terhadap modal kerja

Berdasarkan hasil uji t diperoleh nilai t-hitung sebesar 8,787 > $\mathrm{t}_{\text {-tabel }}$ 2,021 dengan $\mathrm{p}$-value . sebesar $0,000<0,05$. Nilai koefisien regresi variabel current ratio adalah 600,162 (positif). Hal ini memberikan bukti bahwa hipotesis yang diajukan terbukti diterima, current ratio berpengaruh positif signifikan terhadap modal kerja.

Hasil penelitian ini dukung oleh Satar dan Haelani (2016); Priandani dan Lubis (2019) likuiditas berpengatuh positif signifikan terhadap modal kerja.

2) Pengaruh return on assets terhadap modal kerja

Berdasarkan hasil uji t diperoleh nilai t-hitung sebesar 5,465 > $\mathrm{t}_{\text {-tabel }}$ 2,021 dengan $\mathrm{p}$-value . sebesar $0,000<0,05$. Nilai koefisien regresi variabel current ratio adalah 436.402 (positf). Hal ini memberikan bukti bahwa hipotesis yang diajukan terbukti diterima, return on assets berpengaruh positif signifikan terhadap modal kerja.
Hasil penelitian ini di dukung Anggarani dan Ficilia (2014) yang menyatakn profitabilitas memiliki pengaruh dan signifikan terhadap modal kerja. Selanjutnya di bantah oleh Fadli (2017) bahwa ROA tidak berpengaruh signifikan terhadap modal kerja

3) Pengaruh equity terhadap modal kerja

Berdasarkan hasil uji $\mathrm{t}$ diperoleh nilai $\mathrm{t}^{-}{ }_{\text {hitung }}$ sebesar $-5,964<t_{\text {tabel }} 2,021$ dengan $\mathrm{p}$-value . sebesar $0,000<0,05$. Nilai koefisien regresi variabel current ratio adalah -160.804 (negatif). Hal ini memberikan bukti bahwa hipotesis yang diajukan terbukti ditolak, equity berpengaruh negatif signifikan terhadap modal kerja.

Hasil penelitian didukung oleh Fadli (2017) ; Satar dan Haelani (2016) ; Priandini (2019) bahwa ROE tidak berpengaruh signifikan terhadap modal kerja.

\section{PENUTUP}

\section{Kesimpulan}

Hasil analisis data statistik terhadap kontribusi current ratio, return on asset, dan equity pada modal kerja PT. Unilever Indonesia, Tbk, dapat disimpulkan bahwa:

1. Current Ratio berpengaruh positif signifikan terhadap modal kerja

2. Return on assets berpengaruh positif signifikan terhadap modal kerja.

3. Equity berpengaruh negatif signifikan terhadap modal kerja

\section{Saran}

1. Bagi Investor

Investor diharapkan dapat memperhatikan variabel profitabilitas dan likuiditas sebelum mengambil keputusan dalam melakukan investasi pada perusahaan PT. unilever Tbk yang terdaftar di bursa efek indonesia.

2. Bagi perusahaan

Perusahaan diharapkan mampu mempertimbangkan keputusan pendanaan yang diambil baik itu menggunakan modal sendiri ataupun modal asing yang nantinya diharapkan mampu memenuhi kebutuhan atau mencapai tujuan perusahaan.

3. Bagi peneliti selanjutnya

a. untuk peneliti selanjutnya diharapkan untuk menambah jangka waktu pengamatan yang lebih panjang karena semakin lama waktu pengamatan maka semakin besar kesempatan untuk melakukan pengamatan yang akurat. 
b. Untuk Peneliti selanjutnya diharapkan mempertimbangkan menggunakan variabel lainnya. Hasil penelitian ini masih memiliki banyak keterbatasan, sehingga sangat diharapkan untuk peneliti lanjutan menambah variabel-variabel lain yang dapat mempengaruhi modal kerja agar memperluas area penelitian. 


\section{REFERENSI}

Anggarani, D., \& Ficilia, I. (2014). Analisis Pengaruh Profitabilitas dan Risiko terhadap Modal Kerja Bersih pada Perusahaan Tekstil di Bursa Efek Indonesia. Jurnal Manajemen dan Akuntansi, 3(1).

Denziana, A., \& Yunggo, E. D. (2017). Pengaruh Profitabilitas, Struktur Aktiva, Dan Ukuran Perusahaan Terhadap Struktur Modal Perusahaan Pada Perusahaan Real Estate And Property Yang Terdaftar Di Bursa Efek Indonesia Tahun 2015. Jurnal Akuntansi dan Keuangan, 8(1).

Fadli, A. A. Y. (2017). Pengaruh Profitabilitas terhadap Modal Kerja pada Perusahaan Makanan dan Minuman yang Terdaftar di Bursa Efek Indonesia. Jurnal Aplikasi Manajemen, Ekonomi dan Bisnis, 1(2), 120-135.

Fadli, A. (2019). Pengaruh Modal Kerja dan Likuiditas Terhadap Profitabilitas Pada Perusahaan Makanan Dan Minuman Yang Terdaftar Di (BEI). Jurnal Abdi Ilmu, 12(2), 7-19.

Fahmi, Irham. (2014). Pengantar Manajemen Keuangan. Edisi Ketiga. Bandung: Alfabeta, cv.

Fahmi, Irham. (2013). Analisis Laporan Keuangan. Bandung: Alfabeta

Ghozali, Imam. (2016). Aplikasi Analisis Multivariete Dengan Program IBM SPSS 23 (Edisi 8). Semarang : Badan Penerbit Universitas Diponegoro.

Haryanto, T. (2019). Pengaruh Likuiditas dan Perputaran Modal Kerja Terhadap Profitabilitas Pada Pt. Pariwara Komunikasi Indonesia Di Tangerang. Jurnal SEKURITAS (Saham, Ekonomi, Keuangan dan Investasi), 2(2), 113-130.

Jumingan (2014) analisis laporan keuangan. Cetakan kelima. Jakarta: Bumi Aksara

Kasmir. (2010). Pengantar Manajemen Keuangan. Edisi Kedua. Jakarta: Prenamedia Group

Kasmir. (2019). Analisis Laporan Keuangan. Edisi Revisi. Depok: Pt Rajagrafindo Persada.

Khorrunisa, R., Sasongko, H., \& Endah, R. M. (2017). Pengaruh Modal Kerja Terhadap Profitabilitas Pada Pt Mayora Indah, Tbk Periode 2006-2015. Jurnal Online Mahasiswa (JOM) Bidang Akuntansi, 2(2).

Meidiyustiani, R. (2016). Pengaruh Modal Kerja, Ukuran Perusahaan, Pertumbuhan Penjualan dan Likuiditas terhadap Profitabilitas pada perusahaan manufaktur sektor industri barang konsumsi yang terdaftar di Bursa Efek Indonesia (BEI) periode tahun 2010-2014. Jurnal Akuntansi dan Keuangan, 5(2), 41-59.

Priandini, R., \& Lubis, I. (2019). Pengaruh Profitabilitas dan Likuiditas Terhadap Modal Kerja Pt. Indofood Sukses Makmur, TBK. In Prosiding Seminar Nasional Fakultas Ekonomi Untidar.

Syamsuddin, Lukman (2016). Manajemen keuangan perusahaan. Edisi baru, cetakan 13. Jakarta: Rajawali

Sjahruddin, Herman, dkk (2017) Modul Pengolah Data SPSS. Makassar: Stiem Bongaya Makassar

Satar, M., \& Haelani, T. (2016). Pengaruh Frofitabilitas dan Likuiditas Terhadap Modal Kerja (Studi Empiris Pada PT. Unilever Indonesia, Tbk). AKURAT| Jurnal Ilmiah Akuntansi FE UNIBBA, 7(3), 62-79.

Sugiyono. (2013) Metode Penelitian Pendidikan, Pendekatan Kuantitatif, kualitatif dan R\&B. Cetakan ke18. Bandung : Alfabeta

Sudana, Made (2011). Manajemen Keuangan Perusahaan Teori dan Praktik. Edisi 2. Penerbit Erlangga

Sulindawati, dkk.(2017). Manajemen Keuangan. Depok: Pt Rajagrafindo Persada

Sunyoto, Danang. (2013). Analisis Laporan Keuangan untuk Bisnis (Teori dan Kasus). Jakarta: CAPS (Center of Academic Publisisng Service).

www.idx.co.id 